A N NALES

UNIVERSITATIS MARIAE CURIE-SKŁODOWSKA LUBLIN - POLONIA

VOL. XXXV

SECTIO FF

$2-2017$

\title{
AGNIESZKA STAŃCZAK
}

Uniwersytet Marii Curie-Skłodowskiej

\section{Problemy i zjawiska społeczne w wybranych felietonach Piotra Choynowskiego („Tygodnik Ilustrowany” 1928-1929)}

Social Issues and Social Phenomena in Selected Feuilletons by Piotr Choynowski

("Tygodnik Ilustrowany" 1928-1929)

Piotr Choynowski w dwudziestoleciu międzywojennym był uznanym prozaikiem: oprócz krótkich form literackich pisał także powieści ${ }^{1}$. Na temat jego twórczości wypowiadali się m.in.: Adam Grzymała-Siedlecki, Juliusz Kleiner, Jan Lorentowicz, Emil Breitner, Wilhelm Feldman czy Kazimierz Czachowski. Krytycy doceniali jego talent, warsztat pisarski, zdolność obserwacji skupiającej się na najbardziej charakterystycznych szczegółach oraz sposób przedstawiania ludzi i środowiska. Nie byli jednak zgodni w kwestii źródeł inspiracji twórczej: jedni uznawali go za przedstawiciela odradzającego się realizmu, inni sądzili, iż utwory publicysty nawiązują do tradycji naturalizmu, a jeszcze inni dostrzegali w jego pisarstwie różnorodne pierwiastki (Nowakowski, 1972:10). Nie powstały jednak wówczas szkice krytyczne, przynoszące dokładniejszą analizę i ocenę dorobku prozaika:

Na ogół przeważały oceny zdawkowe, powierzchowne, często ze sobą sprzeczne. Przeważały przy tym w wypowiedziach krytycznych recenzje, w związku z czym niewiele powiedziano o źródłach i istocie talentu pisarza, tradycjach literackich oraz ideowo-artystycznym sensie i wartościach pisarstwa Choynowskiego (Nowakowski, 1972:5).

Współcześnie Choynowski jest pisarzem mało znanym, a jego twórczość odeszła w zapomnienie. Doczekał się tylko jednej monografii autorstwa Józefa

\footnotetext{
${ }^{1}$ Spod jego pióra wyszedł tylko jeden dramat - Ruchome piaski.
} 
Nowakowskiego, wydanej w 1972 roku. Publikacja ta stanowi wnikliwe studium poświęcone dziełom Choynowskiego, lecz autor skupia się przede wszystkim na analizie oraz interpretacji nowel i powieści. Tymczasem Choynowski oprócz działalności stricte literackiej zajmował się również publicystyką. Pracował w znanych i cenionych czasopismach. W 1914 roku pełnił funkcję sekretarza redakcji warszawskiego miesięcznika „Sfinks”, a w latach 1920-1922 redagował „Tygodnik Ilustrowany", z którym współpracował potem do 1930 roku, publikując na jego łamach nie tylko nowele, ale także felietony (Czachowski, 1937:433-434).

Felieton jako gatunek ukształtował się w XIX wieku (pierwociny można odnaleźć już w oświeceniu na łamach londyńskiego „Spectatora”), a jego historia jest związana z rozwojem wysokonakładowej prasy. Pierwotnie nazwa felieton ${ }^{2}$ stanowiła określenie działu pisma, w którym zamieszczano nowele, opowiadania, odcinki powieści oraz artykuły na różne tematy. Teksty umieszczano w dolnej części kolumny i wyodrębniano graficznie, odcinając grubą kreską. Z czasem termin ten zaczęto odnosić do osobnej formy publicystycznej o specyficznych cechach (Chudziński, 2010:345-346; Gumkowski, 1991:261; Wojtak, 2004:203).

Do wyznaczników gatunkowych felietonu zaliczano: cykliczność ukazywania się, nieoficjalność, ekspozycję podmiotu autorskiego, tematyczną dowolność ${ }^{3}$, subiektywne ujęcie prezentowanego zagadnienia, posługiwanie się literackimi środkami ekspresji, swobodę stylistyczną oraz nawiązywanie do innych gatunków wypowiedzi ${ }^{4}$. Z powodu swoich właściwości omawiany gatunek publicystyczny stanowił doskonałe narzędzie perswazji, które często wykorzystywano do realizacji społeczno-wychowawczych oraz propagandowo-politycznych celów. Co więcej, teksty zamieszczane w dziale felietonowym były przeznaczone dla masowego odbiorcy, miały zaciekawić czytelników o różnych zainteresowaniach i gustach (stąd tematyczna różnorodność) i w szerszej perspektywie służyły utrwaleniu związków komunikacyjnych między gazetą a czytelnikami (Chudziński, 2010:354; Gumkowski, 1991:261). Największą popularność zyskała kronika, która niebawem stała się głównym reprezentantem gatunku ${ }^{5}$. Odmiana ta nawiązywała do form literackich, takich jak: nowela, humoreska, obrazek czy gawęda. Stanowiła subiektywne, pobieżne i humorystyczne omówienie wyselekcjonowanych wydarzeń określonego odcinka czasowego (zazwyczaj tygodnia), przy czym

${ }^{2}$ Nazwa wywodzi się od francuskiego słowa feuilleton oznaczającego 'kartkę złożoną na czworo' i wiąże się z dodatkiem rozrywkowym do paryskiego „Journal des Débats” drukowanym początkowo na osobnych kartkach.

${ }^{3}$ Zazwyczaj jednak felietony dotyczyły aktualnych wydarzeń i problemów.

${ }^{4}$ Współczesne definicje felietonu również kładą nacisk na wymienione cechy i nie różnią się bardzo od tych formułowanych w XIX w.

${ }^{5}$ Początkowo określenia „kronika” i „felieton” traktowano jako synonimy o odmiennym zabarwieniu emocjonalnym. Tego pierwszego często używano w tytułach cyklów, zaś drugie uważano za kolokwialne i mniej oficjalne. 
wydarzenia te w niektórych tekstach bywały jedynie pretekstem do ogólniejszych rozważań (Gumkowski, 1991:262).

Do klasyków felietonistyki zalicza się Bolesława Prusa, który formę kroniki doprowadził do doskonałości pod względem tematycznym, formalnym i stylistycznym. Felietony publikował od 1874 roku na łamach wielu czasopism, m.in.: „Niwy”, „Kuriera Warszawskiego”, „Nowin” czy „Kuriera Codziennego”. W latach 1905-1911 redagował Kronike tygodniowa w „Tygodniku Ilustrowanym”. Prus pisanie felietonów traktował jako zawód i podkreślał jego utylitarny charakter. Uważał, że kronikarz powinien być fachowcem i erudytą, który obserwuje życie i naturę, gromadzi fakty, aby je następnie zestawić. Nie może dostosowywać się do gustów publiczności, gdyż powinien „wpływać na opinię publiczną, być jej rozumnym korektorem, a nie bezwolnym narzędziem" (Bachórz, 1994:XXV). Jego zdaniem felietonistyka powinna zbliżać się do nauki, stanowić rodzaj działalności badawczej a jednocześnie popularyzatorskiej.

W ,Tygodniku Ilustrowanym” Prus zamieszczał problemowe kroniki eseistyczne, w których rozpatrywał zagadnienia społeczne, polityczne, kulturowe, moralne i filozoficzne. Tematyka wiązała się z patrzeniem na rzeczywistość i człowieka przez pryzmat pozytywistycznych idei. Dlatego też publicysta interesował się gospodarką, warunkami zatrudnienia, wynalazkami, troszczył się o działalność towarzystw filantropijnych, związki sportowe, organizacje oświatowe, apelował o wzajemną pomoc, zrzeszanie się w celu realizowania pożytecznych zadań i tworzenia instytucji potrzebnych społeczeństwu. Ważne dla niego były sprawy wychowania i edukacji młodzieży - zachęcał do kształcenia zawodowego i dokształcania, dostrzegał potrzebę zmiany metod nauczania. Nie pomijał również sztuki: recenzował wystawy, przedstawienia, koncerty, występy śpiewaków i cyrkowców, zastanawiał się nad dziedzictwem literackim przeszłości oraz nad aktualnymi prądami i kierunkami. Doceniał także pracę wybitnych artystów i naukowców, domagając się społecznego uznania i szacunku dla nich (Bachórz, 1994) ${ }^{6}$.

Piotr Choynowski w latach 1928-1929 pisywał do ,Tygodnika Ilustrowanego" felietony pod tym samym tytułem co Bolesław Prus ${ }^{7}$. Pierwszy z drukowanych tekstów poświęcił osobie wielkiego poprzednika, pragnąc „,dać wyraz swemu szczeremu synowskiemu dla niego uczuciu" (Choynowski, 1928a:10). Publicysta nie tylko oddał hołd sławnemu pisarzowi, ale też w pewnym sensie obrał go sobie za mentora i patrona, gdyż w jego artykułach można dostrzec wiele punktów wspólnych z tekstami Prusa.

Choynowski w kronikach podejmował różnorodne tematy ${ }^{8}$, dzielił się przemyśleniami dotyczącymi: pracy pisarskiej, przeczytanych książek lub tłumaczeń

${ }^{6}$ Prus w kronikach podejmował jeszcze wiele innych tematów. Zob.: Bachórz, 1994.

${ }^{7}$ Część z nich wydał w 1930 r. w zbiorze Rzeczy drobne i zabawne.

${ }^{8} \mathrm{Nie}$ wszystkie felietony Choynowskiego są kroniką w węższym zakresie znaczeniowym tego terminu. Sam publicysta określeń „felieton” i „kronika” używa wymiennie, traktując je jako synonimy. 
utworów literackich, obejrzanych filmów, bieżących wydarzeń w Warszawie, w kraju i na świecie; opisywał także ciekawe obyczaje (np. wielkanocna „rybka"); przywoływał zabawne wspomnienia z czasów dzieciństwa i młodości. Jednak najwięcej felietonów poświęcił problemom i zjawiskom społecznym w Polsce $\mathrm{w}$ dwudziestoleciu międzywojennym. Koncentrował się na zagadnieniach związanych z etyką, kulturą i nauką.

Choynowski jako felietonista staje na straży moralności, dostrzega i krytykuje nieuczciwość, okrucieństwo oraz niesprawiedliwość. W kronice z 2 numeru „Tygodnika Ilustrowanego" (dalej skrót: TI) z 1928 roku z oburzeniem pisze o pobiciu pisarza i publicysty Adolfa Nowaczyńskiego ${ }^{9}$. Stwierdza, iż „napadu dokonała dzicz, dzicy ludzie", a zajście trudno uznać za chęć odwetu za obrazę, gdyż „samo pojęcie obrazy każe się domyślać pewnego poczucia rycerskości w obrażonym. Tu owej rycerskości ani śladu" (Choynowski, 1928b:34). Atak na bezbronnego człowieka wygląda raczej na usiłowanie zabójstwa. Choynowski dostrzega w nim także podważenie autorytetu państwa. Jego zdaniem napad ten był samosądem dokonanym przez grupę ludzi, która „w skuteczność wymierzania sprawiedliwości w Polsce nie wierzy" (ibidem), a także okrutną kpiną z państwa, ponieważ napastnicy posługiwali się fałszywymi dokumentami wydziału śledczego i udawali funkcjonariuszy państwowych. Ów „cyniczny żart” może stanowić niebezpieczny precedens, ponieważ osłabia zaufanie obywateli do policji oraz innych służb państwowych. Dlatego publicysta wyraża nadzieję, że sprawcy zostaną szybko zatrzymani i przekonani o skuteczności działania wymiaru sprawiedliwości.

W następnym numerze TI Choynowski porusza kwestię opinii publicznej. Na wstępie zauważa, że po wojnie zmienił się sposób postrzegania i oceniania ludzkich zachowań. Wszyscy stali się niezwykle wyrozumiali, przymykają oczy na niemoralne postępki, unikają osądzania. Wiele rzeczy przestało dziwić i oburzać. Aby nie poprzestać na moralizatorstwie, felietonista podaje przykłady mające świadczyć o zasadności przedstawionych opinii. Przytacza m.in. historię dawnego znajomego, który uciekł za granicę z powodu długów po tym, jak oszukał i naciągnął wielu ludzi. Po wojnie wrócił do Polski, dostał pracę w ambasadzie w Warszawie i stał się szanowanym obywatelem. Choynowski wspomina także o dyrektorze jednego z towarzystw akcyjnych, który w wyniku oszustwa zrujnował wielu ludzi, lecz mimo to wszyscy darzą go uznaniem i zabiegają o jego względy. Publicysta samego siebie zalicza do grona „prymitywnie uczciwych” (Choynowski, 1928b:54) i ubolewa nad upadkiem opinii publicznej. Winą za ten stan rzeczy obarcza inteligencję, która dawniej stała na straży moralności, ale po wojnie ,zrzekła się swej zaszczytnej roli” (ibidem) i straciła wpływ na społeczeń-

\footnotetext{
${ }^{9}$ Pisarz został pobity z powodu radykalnych poglądów skierowanych przeciwko J. Piłsudskiemu i jego zwolennikom. Choynowski pomija jednak w felietonie aspekt polityczny wydarzenia.
} 
stwo. Zaznacza jednak, iż jego zadaniem jako felietonisty nie jest szukanie przyczyn ani proponowanie rozwiązań, lecz wskazywanie na istnienie problemu.

W 8 numerze TI z 1929 roku Choynowski wypomina Polakom brak odwagi cywilnej. Pretekstem do tego stały się doniesienia prasowe o człowieku, który siekierą zamordował teściów, próbował zabić brata, ciężko ranił żonę i córkę, a następnie podpalił własny dom. Felietonistę oburza nie tylko okrucieństwo zbrodni, ale również brak reakcji mieszkańców wsi oraz pasażerów przejeżdżającego autobusu na rozgrywający się na ich oczach dramat. Nikt nie miał odwagi, by pomóc ofiarom i pochwycić mordercę. Choynowski pisze wprost:

Czytelnicy rozumieją już, że zbrodnia ta poruszyła mnie dlatego przede wszystkiem, iż towarzyszące jej okoliczności wskazują brak w naszych masach najprymitywniejszych uczuć społecznych: brak odwagi cywilnej, brak solidarności i brak współczucia ludzkiego dla nieszczęścia. Stwierdzenie to napawa mnie głębokim wstydem i smutkiem (Choynowski, 1929b:146).

Kolejną kwestią wielokrotnie poruszaną przez publicystę $\mathrm{w}$ felietonach jest edukacja. W kronice z 6 numeru TI z 1928 roku przytacza rozmowę z zaprzyjaźnionym profesorem uczelni warszawskiej, który uskarża się na ogromną liczbę studentów podejmujących naukę na uniwersytecie. Powoduje to nie tylko ograniczenie czasu poświęcanego przez naukowców na badania własne, ale także utrudnia pracę z uczniami, gdyż laboratoria i pracownie nie są $\mathrm{w}$ stanie pomieścić wszystkich słuchaczy, brakuje również materiałów dydaktycznych i pomocy naukowych. Odbija się to na poziomie wykształcenia absolwentów. Co więcej, młodzież akademicka nie wykazuje zapału do zdobywania wiedzy, a ze względu na konieczność zapewnienia sobie utrzymania musi łączyć naukę z pracą zarobkową. W związku z tym zaledwie $30 \%$ z nich kończy studia. Zjawisko to skłania Choynowskiego do zastanowienia się, dlaczego tak ogromna rzesza młodych ludzi pragnie kształcić się na uniwersytetach mimo ubóstwa i przepracowania odbijających się na zdrowiu oraz braku perspektyw zawodowych. Felietonista dochodzi do wniosku, iż powodem jest błędne przeświadczenie, że „inteligentny człowiek" musi ukończyć studia. Dyplom uczelni wyższej stał się więc poświadczeniem inteligencji. Według Choynowskiego powyższa sytuacja stanowi poważne niebezpieczeństwo społeczne.

W kronikach z numerów 37 i 41 TI z 1928 roku Choynowski wraca do problemu dużej liczby uczniów w gimnazjach i na uczelniach wyższych oraz grożącego im w przyszłości bezrobocia ${ }^{10}$. Ze względu na potrzeby społeczne opowiada się przeciwko bezmyślnemu masowemu wysyłaniu dzieci do ogólnokształcą-

\footnotetext{
${ }^{10}$ Po I wojnie światowej w Polsce wprowadzono powszechne nauczanie. W połowie dwudziestolecia obowiązkiem szkolnym objęto roczniki wyżu powojennego oraz dzieci ludności przenoszącej się masowo do stolicy, co wraz z kryzysem gospodarczym doprowadziło do ogromnego zagęszczenia w klasach i „katastrofy szkolnej”. W niektórych placówkach klasy liczyły nawet 60 uczniów (por. Królikowski, 2008:581, 600).
} 
cych szkół średnich oraz „naiwnej i szkodliwej wierze rodziców w patenty, dyplomy i tytuły" (Choynowski, 1928j:758). Apeluje o dowartościowanie kształcenia fachowego, pozwalającego nabyć konkretne umiejętności oraz zapewniającego zawód i pracę, co jest niezwykle istotne dla sytuacji gospodarczej kraju po odzyskaniu niepodległości. Warto zauważyć, że poglądy Choynowskiego w tej kwestii były zgodne z ideologią propagowaną przez redakcję „Tygodnika Ilustrowanego", dotyczącą pracy mającej budować przyszłość narodu polskiego (zob. Gabryś-Sławińska, w druku).

W felietonie z numeru 29 (TI 1928) publicysta wskazuje na niepokojące zjawisko w szkołach średnich, czyli publiczne lżenie i bicie nauczycieli przez uczniów, podając przykłady takiego zachowania zaczerpnięte z prasy. Powodem zepsucia młodzieży zdaniem Choynowskiego jest system oświaty, który wymaga gruntownej reformy. Przede wszystkim nauczyciele powinni ze sobą współpracować, tymczasem każdy uważa swoją dziedzinę za najważniejszą i nie bierze pod uwagę indywidualnych zdolności oraz talentów uczniów. Drugi problem to nadmierna koncentracja na wiedzy humanistycznej i zbyt obszerna lista lektur, co skutkuje zniechęceniem uczniów do literatury i szkoły. Ostatnią zaś kwestię stanowi brak dyscypliny i reguł postępowania, co wzmaga uczucie niepewności wśród grona nauczycielskiego i powoduje trudności w pracy z młodzieżą.

Tematami ważnymi i poruszanymi przez Choynowskiego w felietonach są również kultura i sztuka. W kronice z 11 numeru TI z 1929 roku publicysta zwraca uwagę na pojawienie się po wojnie niepokojącego ogólnoświatowego zjawiska zaniedbania „spraw ducha”. W Polsce jest ono jeszcze bardziej widoczne. Społeczeństwo nie interesuje się sztuką, co odbija się na stanie instytucji kultury. Jedyna filharmonia w kraju, aby zapewnić środki finansowe na organizację koncertów, musi wynajmować budynek na kinematograf. Nie ma galerii z wystawami obrazów i rzeźb, książki wybitnych pisarzy drukowane są w niewielkich nakładach. Czasopisma upadają z powodu braku czytelników, a działy krytyczne w prasie są zamieszczane na szarym końcu lub usuwane. Popularność zyskały marne thumaczenia „cudzoziemskiej grafomanii” (Choynowski, 1929c:208), świadczące o braku szacunku dla języka.

Choynowski szczególnie ubolewa nad stanem czytelnictwa w kraju i losem książki polskiej, który po odzyskaniu niepodległości nie jest tak świetny, jak przewidywano. Polacy czytają niewiele. Sięgają jedynie po prasę i literaturę brukową ${ }^{11}$. „Dobra książka nie idzie. Poezyj nie kupuje nikt, na dramat każdy się krzywi, powieści nabywa z westchnieniem" (Choynowski, 1928g:452). Literatura w czasie niewoli stanowiła wyraz tęsknoty narodu za własnym państwem. Po od-

${ }^{11} \mathrm{Z}$ tego powodu po I wojnie światowej podejmowano różne inicjatywy organizacyjne, tworzono związki artystyczne, które często wydawały własne czasopisma, kształtujące świadomość literacką i kulturową. Zob. Mikosz, 2010. 
zyskaniu niepodległości przestała być potrzebna. Niski poziom czytelnictwa skutkuje małymi nakładami, a co za tym idzie - wpływa na wzrost ceny książki, a to odstrasza potencjalnych czytelników i tworzy się błędne koło. Felietonista proponuje, aby państwo wzięło pod opiekę książkę, ,jak bierze pod opiekę każdą inną zagrożoną gałąź życia narodowego" (ibidem), pochwala zabiegi organizacji literackich, domagających się uznania książki za towar uprzywilejowany, obniżenia podatku obrotowego od handlu czy taryf kolejowych i pocztowych oraz utworzenia Akademii Literatury Polskiej ${ }^{12}$ - instytucji, która pielęgnowałaby język ojczysty oraz reprezentowałaby literaturę w kraju i zagranicą.

W innym felietonie Choynowski przedstawia trudności, z jakimi mierzy się w Polsce „zamiłowany czytelnik” (Choynowski 1928i:506). Domowe księgozbiory nie są imponujące i ograniczają się zwykle do podstawowego kanonu lektur. Czytelnicy mogą korzystać z bibliotek publicznych, których jest jednak niezwykle mało i znajdują się wyłącznie w dużych miastach. Co więcej, służą tylko do celów naukowych, a książki wypożyczane są niechętnie (mieszkaniec prowincji nie ma szansy nic wypożyczyć, gdyż przesyłka jest niemożliwa). Ostatnią deską ratunku zdają się „prywatne wypożyczalnie książek”, których w Warszawie nie brakuje. Niestety, nastawione są na zysk, więc ich zaopatrzenie podporządkowane jest gustom publiczności. Wytrawny czytelnik nie znajdzie tam wielu wartościowych publikacji. W innych polskich miastach sytuacja jest jeszcze gorsza, gdyż bibliotek (jakichkolwiek) nie ma tam wcale. Choynowski sugeruje, żeby samorządy przeznaczały co roku niewielkie kwoty na tworzenie bibliotek, co pozornie nie byłoby zadaniem trudnym, gdyby nie fakt, że nikt nie dostrzega takiej potrzeby. Dlatego publicysta stwierdza, że „przydałby się [...] pewien nacisk z góry" (ibidem).

Choynowski nie tylko piętnuje społeczne zaniedbania czy naganne zachowania, lecz jest także wnikliwym obserwatorem codzienności: dostrzega ciekawe zjawiska i pewne społeczno-obyczajowe zmiany. Pisze o powojennych balach i spotkaniach towarzyskich (modne stały się wówczas dancingi; Choynowski, 1928c), o zebraniach towarzystw i specyfice ich członków (Choynowski, 1928f) bądź o społecznym trendzie polegającym na biciu rekordów ${ }^{13}$ w każdej, nawet śmiesznej, dziedzinie (Choynowski, 1928h).

W aż dwóch felietonach (z numerów 16 i 17 TI z 1928 roku) porusza temat szoferów. Na początku ironicznie stwierdza, że automobilizm może rozwiązać

${ }^{12}$ W 1933 r. powstała Polska Akademia Literatury, której zadaniem było dbanie o rozwój literatury polskiej oraz interesy środowiska pisarskiego, a także formułowanie opinii $\mathrm{w}$ sprawach języka, kultury i twórczości literackiej. Instytucja działała do 1939 r. Jednym z jej członków był Choynowski.

${ }^{13}$ Jest to zjawisko znamienne dla tamtych czasów. Redakcja TI chętnie donosiła czytelnikom o kolejnych rekordach i osiągnięciach sportowych, zwłaszcza w dziedzinie motoryzacji (zob. Gabryś-Sławińska, 2016:225-229). 
problemy mieszkaniowe, gdyż wraz ze sprowadzanymi do Polski samochodami rośnie liczba nagłych zgonów:

\begin{abstract}
Za jakieś ćwierć wieku będą w kamienicach same tylko 10-ciopokojowe lokale i w każdym z tych lokali będzie mieszkała jedna tylko rodzina... Rozumie się - rodzina szoferska. Bo do tego czasu ludności pieszej, nieszoferów, zabraknie zupełnie. Toż to będzie uciecha! Będą mogli wybijać na Marszałkowskiej $200 \mathrm{klm}$ na godzinę, a nie marne 80, jak dzisiaj (Choynowski, 1928d:308).
\end{abstract}

Następnie felietonista dzieli szoferów na fachowych i amatorów. Kronikę z numeru 16 poświęca tym pierwszym. Wśród nich wyróżnia kolejne rodzaje: szoferów taksówek i szoferów prywatnych. Taksówkarze jego zdaniem odpowiadają za największą ilość wypadków, są niezwykle ponurzy i dzielą ludzi na dwie nierówne kategorie: „na «gościa», czyli chwilowego i płacącego wspólnika ewentualnego wypadku, i na olbrzymią rzeszę, którą należy przejeżdżać” (ibidem). Pałają szczególną nienawiścią do ludzi przechodzących przez jezdnię, bo oczywiście piesi złośliwie nie korzystają z chodników. Szoferzy wyładowują frustrację za pomocą przekleństw. Choynowski z ironią pisze: „Ileż razy, pędząc jak wiatr taksówką, słuchałem z radością ich doskonałej polszczyzny, zawartej w zdanie króciutkie i silne: «Gdzie leziesz, draniu! Ślepia ci wyżarło?!» albo w formie dobrotliwego życzenia: «Bodaj cię ciężka śmierć! Bodajeś roku nie dożył!»” (ibidem).

Szoferzy prywatni, czyli kierowcy samochodów ludzi zamożnych, stanowią przeciwieństwo taksówkarzy: są zawsze zadowoleni i bardzo uprzejmi, a ludzi przejeżdżają rzadko. Notorycznie jednak oszukują klientów, pozorując uszkodzenia auta, aby wyciągnąć pieniądze na rzekomo konieczną naprawę.

Felieton z kolejnego numeru dotyczy szoferów-amatorów. Choynowski thumaczy, iż cechami różniącymi amatorów od fachowców jest ,namiętność sportowa”, „uniesienie”, ,zapał” i ,święty ogień” (Choynowski, 1928e:326). Amatorzy rekrutują się spośród zwyczajnych osobników wpadających w zachwyt po pierwszej przejażdżce autem na fotelu obok szofera. Człowiek taki wyrabia sobie czym prędzej prawo jazdy i zadłuża się, aby kupić własny pojazd. Zdarza się nawet, że kilku znajomych nabywa wspólny samochód, którym wymieniają się według ustalonego rozkładu. Niestety wśród szoferów z omawianej kategorii znajduje się grupa takich, którzy poza jazdą samochodem potrzebują dodatkowych podniet w postaci mocnych trunków, więc zatrzymują się przed każdą karczmą lub restauracją. W efekcie drogi pełne są ,samochodów «zawianych» i chwiejnych, zataczających się od rowu do rowu" (ibidem), urządzane są szalone wyścigi, a za ostateczny hamulec najczęściej służą przydrożne drzewa i rowy.

Dwie inne kroniki stylizowane są na naukową rozprawkę na temat brydża. Przy czym Choynowski nie zajmuje się teorią gry, lecz w nieco ironiczny sposób pokazuje jej zalety społeczno-pedagogiczne i prezentuje obserwacje poczy- 
nione podczas karcianych rozgrywek, w których sam chętnie brał udział. Tłumaczy, że jest to gra zespołowa, polegająca na współpracy z partnerem. Publicysta podkreśla jednak, iż nie każdy może w brydża grać, gdyż należy do tego posiadać następujące atuty: umiejętność gry, dobry wzrok i mocny charakter. Dalsza część felietonu stanowi przegląd wymienionych warunków. Na podstawie pierwszego kryterium Choynowski wyodrębnia dwie grupy graczy: fuszerów i dobrych graczy. W gronie fuszerów wyróżnia kolejne podtypy: fuszer zasadniczy (,gra średnio, ale dobrze nigdy się grać nie nauczy"; Choynowski, 1929a), fuszer heroiczny (który ma szczęście i ciągle wygrywa, budząc zdumienie innych graczy), fuszer kretyn (nie orientuje się zupełnie w rozgrywce, a po licytacji zdezorientowany dopytuje, w co właściwie gra). Graczy dobrych Choynowski dzieli na spokojnych i niespokojnych. Wśród tych drugich wyróżnia graczy raptusów (którzy „ryczą” i przeklinają) oraz graczy złośników (którzy cierpliwie i bez mrugnięcia okiem notują w pamięci cudze błędy, aby niespodziewanie cisnąć innemu graczowi talią w głowę).

Dwie kolejne cechy potrzebne do gry w brydża Choynowski omawia w osobnej kronice (Choynowski, 1929d). Dobry wzrok oznacza, że gracz potrafi sprytnie zajrzeć w karty przeciwnikowi i zrobić ze zdobytej wiedzy odpowiedni użytek. Natomiast mocny charakter potrzebny jest do znoszenia tzw. „galerii”, czyli osób, które nie biorą udziału w grze, lecz ją obserwują i komentują. Wśród kibiców Choynowski wydziela pewne typy: dobry gracz, który nie może znaleźć partnera z powodu swojego charakteru (krytykuje wybranego gracza po nieudanych wyjściach, po czym wyrywa mu z rąk karty i gra za niego), oraz uznany fuszer (ofiarami jego krytycznych uwag padają gracze mający w danej partii pecha do kart). Do „galerii” należą również panie flirtujące zawsze z najmłodszymi graczami, co drażni pozostałych i zakłóca grę.

Z felietonów Choynowskiego wyłania się ciekawy obraz życia w międzywojennej Polsce. Publicysta zwraca uwagę na jego różnorodne aspekty i odsłony: od stosunku społeczeństwa do wartości moralnych, przez problemy oświatowe i kulturalne, po interesujące zjawiska związane z kręgami towarzyskimi, panującymi trendami i życiem w mieście. W jego felietonach pobrzmiewa echo wartości pozytywistycznych, a w doborze zagadnień można dostrzec podobieństwo do publicystyki Prusowskiej. Ze względu na tematykę, prezentowane opinie i akcentowane wartości kroniki Choynowskiego wpisują się również w tradycję i politykę „Tygodnika Ilustrowanego", który swoją działalność traktował jako służbę społeczną.

Należy zaznaczyć, iż Choynowski z powagą podchodzi do kwestii dotyczących etyki, szkolnictwa i kultury. Odważnie i wyraźnie daje do zrozumienia, po stronie jakich wartości się opowiada. Bez ogródek wytyka społeczne wady, zaniedbania, brak inicjatywy i zainteresowania sprawami, o które powinien się troszczyć każdy obywatel. Nie pozwala sobie jednak na emocjonalne wybuchy, ale raczej stara się przekonać czytelników logicznym wywodem, apeluje o dostrzeże- 
nie problemu i podjęcie refleksji. Niewiele w tych kronikach ironii i humoru, a ich dosyć poważny, dydaktyczno-moralizatorski ton jest znamienny, tym bardziej że felietony mają na ogół zapewniać czytelnikowi rozrywkę.

Nieco inny charakter mają teksty podejmujące tematykę codziennego życia zwykłych obywateli, osobliwych zjawisk i praktyk społecznych. Choynowski jest wnikliwym obserwatorem, skupiającym się na błahych, aczkolwiek interesujących, zagadnieniach i sytuacjach. Swoje spostrzeżenia chętnie prezentuje w sposób ironiczny i humorystyczny (ale pozbawiony drwiny), eksponując i czasem nieco wyolbrzymiając ludzkie przywary i śmieszne zachowanie.

Choynowski pisał felietony nie tylko po to, aby zaciekawić czytelników i dostarczyć im rozrywki. Dostrzegał istotne problemy, niepokojące zjawiska; wykorzystywał pozycję felietonisty, aby o nich mówić i uświadamiać społeczeństwo. Jego kroniki stały się świetnym narzędziem perswazji oraz cenną lekcją dla ówczesnych Polaków.

\section{BIBLIOGRAFIA}

Bachórz, J. (1994). Wstęp. W: B. Prus. Kroniki. BN I 285. Wrocław: Zakład Narodowy im. Ossolińskich.

Choynowski, P. (1928a). Kronika tygodniowa. Tygodnik Ilustrowany, 1, s. 10.

Choynowski, P. (1928b). Kronika tygodniowa. Tygodnik Ilustrowany, 2, s. 34.

Choynowski, P. (1928c). Kronika tygodniowa. Tygodnik Ilustrowany, 8, s. 152.

Choynowski, P. (1928d). Kronika tygodniowa. Tygodnik Ilustrowany, 16, s. 308.

Choynowski, P. (1928e). Kronika tygodniowa. Tygodnik Ilustrowany, 17, s. 326.

Choynowski, P. (1928f). Kronika tygodniowa. Tygodnik Ilustrowany, 21, s. 398.

Choynowski, P. (1928g). Kronika tygodniowa. Tygodnik Ilustrowany, 24, s. 452.

Choynowski, P. (1928h). Kronika tygodniowa. Tygodnik Ilustrowany, 25, s. 470.

Choynowski, P. (1928i). Kronika tygodniowa. Tygodnik Ilustrowany, 27, s. 506.

Choynowski, P. (1928j). Kronika tygodniowa. Tygodnik Ilustrowany, 41, s. 758.

Choynowski, P. (1929a). Kronika tygodniowa. Tygodnik Ilustrowany, 7, s. 126.

Choynowski, P. (1929b). Kronika tygodniowa. Tygodnik Ilustrowany, 8, s. 146.

Choynowski, P. (1929c). Kronika tygodniowa. Tygodnik Ilustrowany, 11, s. 208.

Choynowski, P. (1929d). Kronika tygodniowa. Tygodnik Ilustrowany, 12, s. 227.

Chudziński, E. (2010). Felieton. Geneza i ewolucja gatunku. W: Z. Bauer, E. Chudziński (red.). Dziennikarstwo i świat mediów. Nowa edycja. Kraków: Universitas.

Czachowski, K. (1937). Choynowski Piotr. W: W. Kopczyńskie (re.). Polski słownik biograficzny (t. 3, s. 433-434). Kraków: Polska Akademia Umiejętności.

Gabryś-Sławińska, M. (2016). Transport miejski na łamach „, Tygodnika Ilustrowanego” w latach 1918-1928 (rekonesans). W: M. Święcicka, M. Peplińska (red.). Miasto. Przestrzeń zróżnicowana językowo, kulturowo i spolecznie. Bydgoszcz: Wydawnictwo Uniwersytetu Kazimierza Wielkiego.

Gabryś-Sławińska, M. (w druku). Praca w czasach Wielkiej Wojny na łamach „, Tygodnika Ilustrowanego". W: Praca ludzka. Lublin.

Gumkowski, M. (1991). Felieton. W: J. Bachórz, A. Kowalczykowa (red.). Stownik literatury XIX wieku (s. 260-264). Wrocław: Zakład Narodowy im. Ossolińskich. 
Królikowski, L. (2008). Szkolnictwo dawnej Warszawy. Rzecz o korelacji pomiędzy rozwojem miasta a szkolnictwem (Od połowy XVII wieku do wybuchu drugiej wojny światowej). Warszawa: Muzeum Historyczne m.st. Warszawy.

Mikosz, J. (2010). Rola dodatków kulturalnych prasy codziennej w procesie odbudowy państwa polskiego $w$ dwudziestoleciu międzywojennym. W: K. Stępnik, M. Rajewski (red.). Komunikowanie $i$ komunikacja $w$ dwudziestoleciu międzywojennym. Lublin: Wydawnictwo UMCS.

Nowakowski, J. (1972). Piotr Choynowski. Zarys monograficzny. Rzeszów: Wyższa Szkoła Pedagogiczna.

Wojtak, M. (2004). Felieton. Informacja zakamuflowana. W: M. Wojtak. Gatunki prasowe (s. 202237). Lublin: Wydawnictwo UMCS.

\section{STRESZCZENIE}

Polski powieściopisarz i nowelista Piotr Choynowski był również autorem kilkudziesięciu felietonów opublikowanych na łamach „Tygodnika Ilustrowanego” w latach 1928-1929. Dzielił się w nich przemyśleniami dotyczącymi pracy literackiej, wspomnień z młodości czy bieżących wydarzeń mających miejsce w Warszawie, w kraju lub na świecie. Pisał o indywidualnych obserwacjach codziennego życia i nie bał się podejmować poważnych tematów związanych z problemami etycznymi, oświatowymi czy kulturalnymi w dwudziestoleciu międzywojennym. Felietony Choynowskiego miały nie tylko dostarczać czytelnikom rozrywki, ale także zwracać uwagę na aktualne problemy i skłaniać do refleksji.

Słowa klucze: Piotr Choynowski, „Tygodnik Ilustrowany”, felieton, problemy i zjawiska społeczne

\section{SUMMARY}

Polish novelist Piotr Choynowski was also the author of dozens of articles published in "Tygodnik Ilustrowany" in the years 1928-1929. He shared there his thoughts on literary work, memories of youth and discussed current events taking place in Warsaw, Poland or in the world. Although he wrote mainly about everyday life, he was also not afraid to engage in important topics related to ethics and educational or cultural issues in the interwar period. Feuilletons by Choynowski not only provided readers with entertainment, but also highlighted the current problems and prompted reflection.

Keywords: Piotr Choynowski, "Tygodnik Ilustrowany", feuilleton, social issues and social phenomena 